\title{
Effect of UV-C and Ozone on the Bioactive Compounds and Antioxidant Capacity of Minimally Processed Rocket (Eruca Sativa Mill.)
}

\author{
Diego R. Gutiérrez, Laura Lemos, Silvia del C. Rodríguez
}

\begin{abstract}
In this study, treatments with UV-C radiation (10, 20 and $30 \mathrm{~kJ} / \mathrm{m} 2)$ and gaseous ozone $(1,5$ and $10 \mathrm{mg} / \mathrm{L})$ were applied to minimally processed rocket (Eruca sativa) leaves to investigate their effects on the bioactive compounds and antioxidant capacityduring12 days of storage at $5^{\circ} \mathrm{C}$.As control, water washing was used. Ascorbic acid content, phenolic compounds, antioxidant capacity and chlorophyll a and b, total chlorophyll and total carotenoids content throughout shelf-life were studied. The results showed that UV-C and ozone treatments had no adverse effects on ascorbic acid content, phenolic compound and antioxidant capacity of minimally processed rocket leaves. Treatments with UV-C delayed the degradation of total chlorophyll content throughout shelf-life, while the treatments with $\mathrm{O3}$ did not affect this parameter. In conclusion, the UV-C and ozone treatments applied maintain the bioactive compounds with antioxidant activity content of minimally processed rocket leaves during 12 days of storage at 5 ${ }^{\mathbf{o}} \mathbf{C}$.
\end{abstract}

Index Terms - UV-C; ozone; rocket; bioactive compounds; antioxidant capacity.

\section{INTRODUCTION}

The high consumption of fruits and vegetables contribute to the prevention of chronic diseases in which cardiovascular diseases and different types of cancer are included [1]. Minimally processed vegetables are products considered to be good sources of bioactive compounds [2]. Demand for these products has increased worldwide due to changes in demographics, lifestyles and eating habits [3].

The rocket (Eruca sativa Mill.) is an example of a minimally processed product consumed in Mediterranean countries. Its vegetable is a member of the family Brassicaceae that is distinguished by its pleasant bitter taste and also by its content of phytonutrients that stimulate health such as provitamin A, vitamin $\mathrm{C}$, carotenoids, and other mineral nutrients [4-7].The consumption of these compounds exerts a beneficial effect on human health, due to its antioxidant properties that inactivate

Diego R. Gutiérrez, PhD. Posdoc student at CONICET-Argentina Center for Research in Applied Biophysics and Food (CIBAAL-CONICET-UNSE). Faculty of Agronomy and Agroindustries. National University of Santiago del Estero. RN 9, Km 1125. Villa El Zanjón. (CP 4206) - Santiago del Estero. Argentina.

Laura Lemos, Food Engineer. PhD student at CONICET-Argentina. Center for Research in Applied Biophysics and Food (CIBAAL-CONICET-UNSE). Faculty of Agronomy and Agroindustries. National University of Santiago del Estero. RN 9, Km 1125. Villa El Zanjón. (CP 4206) - Santiago del Estero. Argentina.

Silvia del C. Rodríguez, PhD. Professor at National University of Santiago del Estero-Argentina. Institute of Food Science and Technology-Faculty of Agronomy and Agroindustries -National University de Santiago del Estero, Belgrano (S) 1912, Santiago del Estero, Argentina the reactive oxygen species and free radicals. Therefore, the presence of natural antioxidants in the diet guarantees greater protection against cancer and cardiovascular diseases [8,9]. For example, phenolic compounds show positive health effects, which include phenyl carboxylic acids such as gallic acid and vanilla, phenylpropene acids, as well as flavonoids and stilbenes [10].However, fresh-cut products may suffer the outbreak of foodborne diseases and the deterioration of their physiological and chemical properties if handling and processing conditions are inadequate during postharvest $[11$, 12]. Therefore, it is very important to develop effective methods to prolong the fresh state as well as to preserve or even increase the content and activity of the antioxidant compounds of fresh products. In this way, the marketability of these products would be improved and would have positive effects on human health with the consumption of fruits and vegetables [6, 13].

There are tools to extend the shelf life of fresh-cut products such as modified atmosphere packaging (MAP) and refrigeration. However, its general effectiveness is strictly conditioned by initial contamination and quality levels [6].Therefore, it is important to use new and alternative non-thermal technologies to extend the post-harvest life of fruits and vegetables $[6,14]$. In the USA, UV-C radiation was approved as a surface disinfection treatment in food (USDA-FDA, 2002), being as effective as $\mathrm{NaClO}$ or $\mathrm{O}_{3}[15$, 16]. Cisneros-Zevallos [17] hypothesizes that abiotic stress, such as UV-C radiation treatment, could affect the secondary metabolism and increase the synthesis of phytochemicals with nutraceutical activity of the fresh products.In this way, it has been reported that treatment with UV-C increases flavonoids and total phenolic compounds and tends to increase the shelf life of horticultural products [18-20].It has also been reported that UV radiation showed an improvement of total phenols and polyamine compounds in mangoes [21], anthocyanins, phenolic content and antioxidant capacity in strawberries [22] and acid ascorbic, phenolic compounds and antioxidant activity in tomatoes [23].

Another disinfecting agent approved by the US-FDA (2001) for the food industry is ozone. Ozone decomposes rapidly in oxygen and leaves no toxic waste, which makes it attractive and useful for the food industry [19, 24]. Its application is due to its effectiveness in prolonging the shelf life of fresh-cut products by inhibiting the growth of microorganisms and preventing fungal decomposition [12]. Forney [25] also reported that ozone can cause oxidative stress in the tissues of plants and in this way induce diverse physiological responses, such as the synthesis of phenolic compounds, antioxidants 
and other secondary metabolites.In this way, research has shown that gaseous ozone had a positive effect on changes in the content of antioxidant components, for example, flavonoids and other phenolic compounds [19].

The objective of this study was to determine the effects of UV-C and ozone on bioactive compounds and antioxidant capacity of minimally processed rocket stored at $5{ }^{\circ} \mathrm{C}$.

\section{MATERIALS AND METHODS}

\section{A.Plant material}

Rocket (Eruca Sativa Mill.) leaves were provided by local producer in Santiago del Estero, Argentina. Immediately after harvest the leaves were transported to the laboratory, where they were stored in a cold room at $5{ }^{\circ} \mathrm{C}$ in darkness. Next day, the leaves were minimally processed in a disinfected room at $16{ }^{\circ} \mathrm{C}$.

\section{B. UV-C and ozone equipment's}

The UV-C equipment consisted of a reflective stainless steel chamber, equipped with 12 unfiltered germicidal lamps (254.7 nm, TUV 36W/G36 T8, Philips, Amsterdam, The Netherlands), of which 6 were at the top and 6 at the bottom of the chamber. The equipment has been fully described by Gutiérrez et al.[6]. Light intensity at wavelength of $254 \mathrm{~nm}$ was kept constant. The applied doses varied by modifying the exposure time.

The $\mathrm{O}_{3}$ was generated by an ozone generator (Bio3 Ozone Generator Model TDZ-1, Uruguay) with a production capacity of $1 \mathrm{~g} / \mathrm{h}$ of ozone and the ozone concentration in the chamber was recorded via an ozone analyzer (Gas Alert Extreme $\mathrm{O}_{3}$ - BW Technology, Honeywell, Canada). The flow and treatments with $\mathrm{O}_{3}$ had been described by Gutiérrez et al.[6].

C. Sample preparation, treatmentsand storage conditions

Rocket leaves were inspected and those that showed physically damaged, dehydrated or without the characteristic color (yellowed) were removed. After selection performed in a disinfected area at cool room (about $8{ }^{\circ} \mathrm{C}$ ), the leaves were washed with tap water $\left(5^{\circ} \mathrm{C}\right)$ for $1 \mathrm{~min}$ and drained on a stainless-steel mesh. The leaves were cut in strips of about 20 $\mathrm{mm}$ in size with a sharp stainless-steel knife disinfected and were washed for $2 \mathrm{~min}$ at $5{ }^{\circ} \mathrm{C}$. The remaining water of the cut leaves was removed using a manual centrifuge and then were submitted to following treatments with UV-C and $\mathrm{O}_{3}$ :

$\mathrm{T}_{1}$ (control): the cut leaves were washed for $2 \mathrm{~min}$ at $5{ }^{\circ} \mathrm{C}$. Surface excess water was removed using a handheld salad spinner for $45 \mathrm{~s}$. Approximately $60 \mathrm{~g}$ of rocket were placed in $600 \mathrm{~mL}$ polypropylene (PP) trays were sealed at the top with a bioriented PP film of $35 \mu \mathrm{m}$ in thickness to generate a passive MAP. The $\mathrm{O}_{2}$ and $\mathrm{CO}_{2}$ transmission rates at $25^{\circ} \mathrm{C}$ and $90 \%$ RH of BOPP was: $5,000 \mathrm{~mL} \mathrm{O} / \mathrm{m}^{2} / 24 \mathrm{~h} / \mathrm{atm}$ and $18,000 \mathrm{~mL}$ $\mathrm{CO}_{2} / \mathrm{m}^{2} / 24 \mathrm{~h} / \mathrm{atm}$ and the water vapor transmission rate were $110 \mathrm{~g} / \mathrm{m} / 24 \mathrm{~h} / \mathrm{atm}$ (data provided by INTI, Argentina). $\mathrm{T}_{2}\left(10 \mathrm{~kJ} / \mathrm{m}^{2}\right)$ : This treatment was the same as $\mathrm{T}_{1}$ but the cut leaves were subjected to $10 \mathrm{~kJ} \mathrm{UV-C} / \mathrm{m}^{2}$ radiation. Then the leaves were packaged under passiveMAP. $\mathrm{T}_{3}(20$ $\mathrm{kJ} / \mathrm{m}^{2}$ ): This treatment was the same as $\mathrm{T}_{2}$ but the UV-C dose was $20 \mathrm{~kJ} / \mathrm{m}^{2} \cdot \mathrm{T}_{4}\left(30 \mathrm{~kJ} / \mathrm{m}^{2}\right)$ : This treatment was the same as $\mathrm{T}_{2}$ but the UV-C dose was $30 \mathrm{~kJ} / \mathrm{m}^{2} . \mathrm{T}_{5}(1 \mathrm{ppm})$ : This treatment was the same as $\mathrm{T}_{1}$ but the cut leaves were subjected to $1 \mathrm{ppm} \mathrm{O}_{3}$ for $10 \mathrm{~min}$. Then the leaves were packaged under passive MAP as described above. $\mathrm{T}_{6}(5 \mathrm{ppm})$ : This treatment was the same as $\mathrm{T}_{5}$ but $\mathrm{O}_{3}$ concentration was 5 ppm for $10 \mathrm{~min} . \mathrm{T}_{7}(10 \mathrm{ppm})$ : This treatment was the same as $\mathrm{T}_{5}$ but $\mathrm{O}_{3}$ concentration was $10 \mathrm{ppm}$ for $10 \mathrm{~min}$. The trays were stored in a dark cold room at $5{ }^{\circ} \mathrm{C}$. Five replicates, each comprising a tray, per treatment and storage time were prepared. Measurements of the different parameters were undertaken after the treatments and after 1, 4, 8 and 12 days of storage.

\section{Ascorbic acid content}

A sample of $2 \mathrm{~g}$ of leaves of each treatment was homogenized in $20 \mathrm{~mL}$ of $6 \%(\mathrm{w} / \mathrm{v})$ trichloroacetic acid (TCA) and the mixture was kept in darkness for an hour. The homogenate was centrifuged at $12,000 \times \mathrm{g}$ at $4{ }^{\circ} \mathrm{C}$ for $20 \mathrm{~min}$ and the supernatant was used for measurements.Both the ascorbic acid (AA) and dehydroascorbic (DHA) acids contents were determined using a UV-visible spectrophotometer (JASCO, model V-630, Japan) following Kampfenkel et al. [26]. Thus, a standard AA solution was employed for identifying and quantifying these contents in reference to a standard curve while DHA content resulted out of the difference between the total Vitamin $\mathrm{C}$ content and AA. The results were expressed as AA in $\mathrm{mg} / 100 \mathrm{~g}$ of fresh weight $(\mathrm{FW})$. All measurements were made in triplicate.

\section{E. Extraction and determination of Phenolic}

The phenolic compounds of the samples were extracted as described by Gutiérrez et al. [5]; For each day of measurement, samples $(10 \mathrm{~g})$ of each replicate treatment were frozen at $-80{ }^{\circ} \mathrm{C}$ (Ultrafrezzer Righi, Argentina) and stored until chemical determinations were performed. The $4 \mathrm{~g}$ frozen rocket samples were homogenized using $20 \mathrm{~mL}$ of methanol and centrifugated for $15 \mathrm{~min}$ at $6000 \times \mathrm{g}$ at $4{ }^{\circ} \mathrm{C}$. The supernatant of each sample was used as an extract. The amount of total phenolic compounds was determined as described previously by Singleton et al. [27]. A $0.5 \mathrm{~mL}$ aliquot of this extract was mixed with $8 \mathrm{~mL}$ of distilled water and mixed together with $0.5 \mathrm{~mL}$ of Folin-Ciocalteu reagent $(1: 1 \mathrm{v} / \mathrm{v}$, diluted with distilled water). After $3 \mathrm{~min}, 1 \mathrm{~mL}$ of 5 $\% \mathrm{Na}_{2} \mathrm{CO}_{3}$ solution was added with vigorous shaking to the solution. The mixture was then incubated for $1 \mathrm{~h}$ at $25^{\circ} \mathrm{C}$ in darkness measuring the absorbance at $765 \mathrm{~nm}$ using a UV-vis spectrophotometer (JASCO V-630). The total phenolic content was expressed as chlorogenic acid equivalents (CAEq) in $\mathrm{g} / \mathrm{kg}$ of $\mathrm{FW}$. All the measures were made in triplicates.

\section{F. Antioxidant capacity}

The ferric reducing antioxidant power (FRAP) assay and the 2,2-diphenyl-1-picrylhydrazyl (DPPH) free radical-scavenging method were used to evaluate antioxidant capacity.

The FRAP assay followed the method described by Benzie and Strain[28] (1996). Firstly, FRAP reagent was prepared by mixing $0.1 \mathrm{M}$ acetate buffer $(\mathrm{pH} 3.6), \quad 10 \mathrm{mM}$ 2,4,6-tris(2-pyridyl)-s-triazine (TPTZ) and $20 \mathrm{mM}$ ferric 
chloride in the ratio of 10:1:1 (v/v/v). Sample extraction was conducted as described in total phenolics. A $0.1 \mathrm{~mL}$ aliquot of the sample extract was added to $4.9 \mathrm{~mL}$ of FRAP reagent and incubated in a water bath of $37{ }^{\circ} \mathrm{C}$. The absorbance was measured at $593 \mathrm{~nm}$ after $10 \mathrm{~min}$, and $0.1 \mathrm{~mL}$ of $80 \%$ methanol adding to $4.9 \mathrm{~mL}$ of FRAP reagent was prepared as the control solution.

The 2,2-diphenyl-1-picrylhydrazyl (DPPH) free radical-scavenging method was used to evaluate antioxidant capacity according to Brand Williams et al. [29]. Thus, a 150 $\mu \mathrm{L}$ aliquot of each extract was added with $2850 \mu \mathrm{L}$ of a $0.1 \mathrm{mM}$ DPPH solution (prepared with ethanol) and the mixture kept in dark for one hour at room temperature. The absorbance at $515 \mathrm{~nm}$ was measured at different times with a spectrophotometer (JASCO V-630, UV-vis). The calibrating curve was depicted using Trolox as standard and the results are expressed as Trolox equivalents (Trolox Eq) in $\mathrm{g} / \mathrm{kgF}$.W. All the measurements were made in triplicate.

\section{G. Chlorophyll and Carotenoid Content}

For tissue preparation, $5 \mathrm{~g}$ of leaves of each treatment were frozen at $-80^{\circ} \mathrm{C}$. A sample of $0.4 \mathrm{~g}$ of frozen rocket $\left(-80^{\circ} \mathrm{C}\right)$ was triturated with $15 \mathrm{~mL}$ of acetone/water (80:20), then centrifuged at $5,000 \times \mathrm{g}$ for $15 \mathrm{~min}$. The supernatant was used to determine the total chlorophyll content, chlorophyll $\mathrm{a}$ and $\mathrm{b}$ and total carotenoids according to Lichtenthaler [29]. The absorbance (A) at 663.2, 646.8 and $470 \mathrm{~nm}$ was measured using a UV-visible spectrophotometer (JASCO, model V-630, Japan). The equations developed by Lichtenthaler [29] were used to determine the individual levels of chlorophyll a $\left(\mathrm{Ca}=12.25 \mathrm{~A}_{663.2}-2.79 \mathrm{~A}_{646.8}\right)$, chlorophyll b $\left(\mathrm{Cb}=521.5 \mathrm{~A}_{646.8}-5.1 \mathrm{~A}_{663.2}\right)$, total chlorophyll amount $(\mathrm{Ca}$ $+\mathrm{Cb})$ and total carotenoids $\left[\mathrm{C}_{\mathrm{x}+\mathrm{c}}=\left(1000 \mathrm{~A}_{470}-1.82 \mathrm{Ca}-\right.\right.$ $85.02 \mathrm{Cb}) / 198]$. Chlorophyll and carotenoids contents were expressed as mg per $100 \mathrm{~g}$ of FW. All measurements were made in triplicate.

\section{H. Statistical analysis}

The experiments were performed using a randomized design based on a bifactorial design. Their statistical analyses were performed using the Infostat software (version 2011, National University of Cordoba, Argentina). Both the analysis of variance (ANOVA) and the Least Significant Difference (LSD) tests were applied to evaluate the influence of either the treatment and the storage time upon data of chlorophyll and carotenoid, ascorbic and dehydroascorbic acid, phenols and antioxidant capacity. Mean values were subjected to the Least Significant Difference (LSD) test at $\mathrm{p}<$ 0.05 .

\section{RESULTS AND DISCUSSION}

\section{A.Ascorbic acid}

The application of treatments UV-C or ozone had no significant influence on initial AA content compared to the control. Then, the ascorbic acid content in all samples decreased significantly $(\mathrm{p}<0.05)$ during the 12 days of storage at $5{ }^{\circ} \mathrm{C}$. However, no significant differences were found either between the different treatments or treatments with respect to the control (Fig. 1A and 2A). These results with UV-C radiation are consistent with that reported in fruits treated with UV-C such as blueberries [31], fresh-cut watermelon [16] and Satsuma mandarin [18].

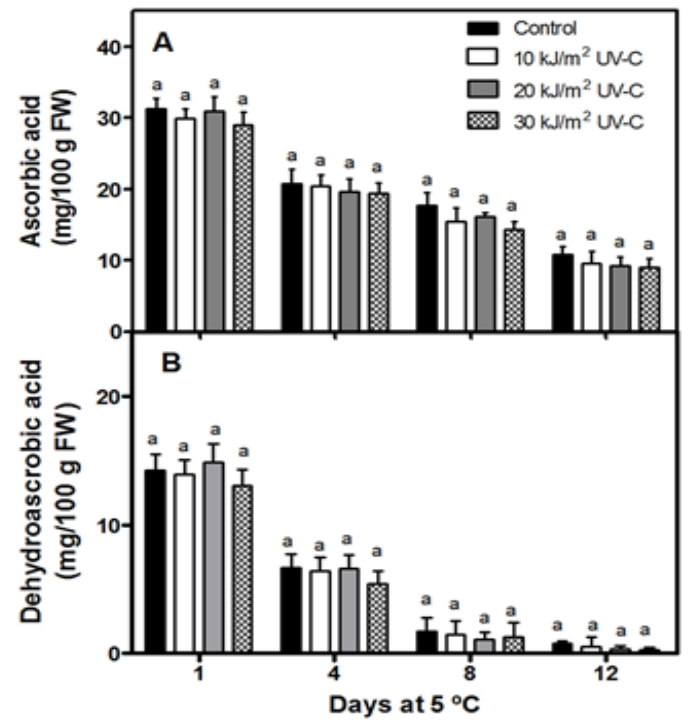

Fig. 1: Content of ascorbic acid (A) and dehydroascorbic acid (B) of minimally processed rocket leaves untreated (control) and treated with UV-C radiation (10, 20 and 30 $\mathrm{kJ} / \mathrm{m}^{2}$ ) and stored at $5{ }^{\circ} \mathrm{C}$ for 12 days. Different letters at each storage time represent significant differences at $\mathrm{P}<0.05$ according to LSD test.

Our results in ozone agree with Glowacz and Rees [32], who found that the ascorbic acid content was not affect in red and green chilli peppers treated with $\mathrm{O}_{3}(0.45,0.9$ and 2 $\mu \mathrm{mol} / \mathrm{mol}$ ) during 10 days of storage at $10^{\circ} \mathrm{C}$. Similarly, AA content was not altered in whole tomatoes cyclically exposed to gaseous ozone at $4 \mu \mathrm{mol} / \mathrm{mol}$ for $30 \mathrm{~min}$ every $3 \mathrm{~h}$ [33].

During food storage, the degradation reactions that occur the ascorbic acid are responsible for important changes in quality, limiting its shelf life. When products are treated with strong oxidants, losses of antioxidant compounds such as ascorbic acid can occur [24]. In this way, Yeoh et al. [12] reported that fresh-cut papaya treated with ozone for 30 minutes significantly decreased the content of ascorbic acid after a prolonged exposure at $6.87 \mathrm{mg} / 100 \mathrm{~g} \mathrm{FW}$ with respect to the control. Similarly, other studies also reported that the concentration of ascorbic acid was reduced by prolonged exposure to ozone in fresh-cut lettuce [34] and carrot sticks [35].

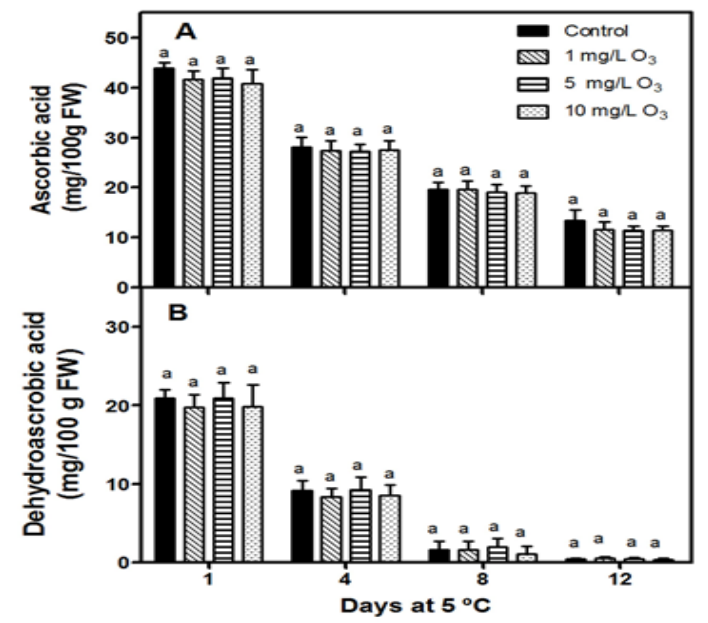

Fig. 2: Content of ascorbic acid (A) and dehydroascorbic 
acid (B) of minimally processed rocket leaves untreated (control) and treated with gaseous $\mathrm{O}_{3}(1,5$ and $10 \mathrm{mg} / \mathrm{L})$ and stored at $5{ }^{\circ} \mathrm{C}$ for 12 days. Different letters at each storage time represent significant differences at $\mathrm{P}<0.05$ according to LSD test.

\section{B. Dehydroascorbic acid content}

The dehydroascorbic acid (DHA) content showed a significant decrease during the 12 days of storage at $5{ }^{\circ} \mathrm{C}$ for all treatments (Fig 1B and 2B). No significant differences were observed in the DHA content between the control and the treatments with UV-C or ozone, both immediately after processing and through the shelf life. The decrease observed in AA levels could be mainly due to the oxidative degradation caused by minimal processing even though the treatments with UV-C and ozone had no additional effects on its degradation.

C. Phenolic compounds and antioxidant capacity Initially, no significant differences between the UV-C treatments or treatments UV-C with respect to the control were observed in the total phenolic content which ranges from 2.0 to $2.2 \mathrm{mg} \mathrm{CAEq} / \mathrm{g} \mathrm{FW}$; this range remained practically constant for all the treatments at $5{ }^{\circ} \mathrm{C}$. No significant differences between the control and treated samples with UV-C were either found at the end of storage (Fig. 3).

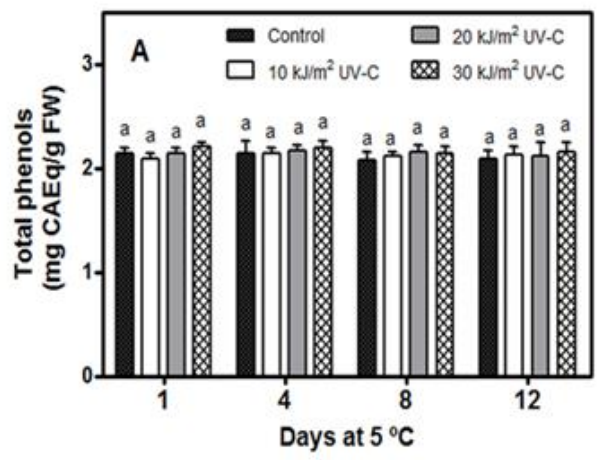

Fig. 3: Content of total phenolicof minimally processed rocket leaves untreated (control) and treated with UV-C radiation $\left(10,20\right.$ and $\left.30 \mathrm{~kJ} / \mathrm{m}^{2}\right)$ and stored at $5{ }^{\circ} \mathrm{C}$ for 12 days. Different letters at each storage time represent significant differences at $\mathrm{P}<0.05$ according to LSD test.

Initial total antioxidant capacity measured by both methods (DPPH and FRAP) did not register any significantly differences between treatments, showed similar ranged between 1.82-1.84 mg Trolox Eq/g FW and 2.32-2.34 mg Trolox Eq/g FW, respectively. As observed for total phenol content, treatments did not show significant variations along storage at $5{ }^{\circ} \mathrm{C}$. No significant differences among treatments were found throughout the shelf-life (Fig. 4 A, B).

These results with UV-C radiation agree with those reported by Martínez-Hernández et al. [36], who reported that treatments with UV-C $\left(6 \mathrm{~kJ} / \mathrm{m}^{2}\right)$ in Kailan hybrid broccoli did not affect the total phenolic content after radiation or during storage at $5^{\circ} \mathrm{C}$ for 19 days. In the same way, Shen et al. [18] reported in minimally processed Satsuma mandarin treated with doses of UV-C of $0.75,1.5$ and $3.0 \mathrm{~kJ} / \mathrm{m}^{2}$ did not cause marked changesin antioxidant capacityand this could be due to the contribution to the antioxidant capacity of the phenolic compounds as well as the ascorbic acid. Different authors related the total phenolic content with the antioxidant capacity [37, 38].

However, in contrast to our results, it has been reported that $\mathrm{UV}-\mathrm{C}$ radiation increased the content of phenolic compounds accompanied by an increase in the antioxidant capacity of strawberry fruits [22], fresh-cut mangoes [21] and minimally processed yam slices [37]. Park and Kim [39] reported that tissue stress caused by UV-C radiation can stimulate the synthesis of secondary metabolites.

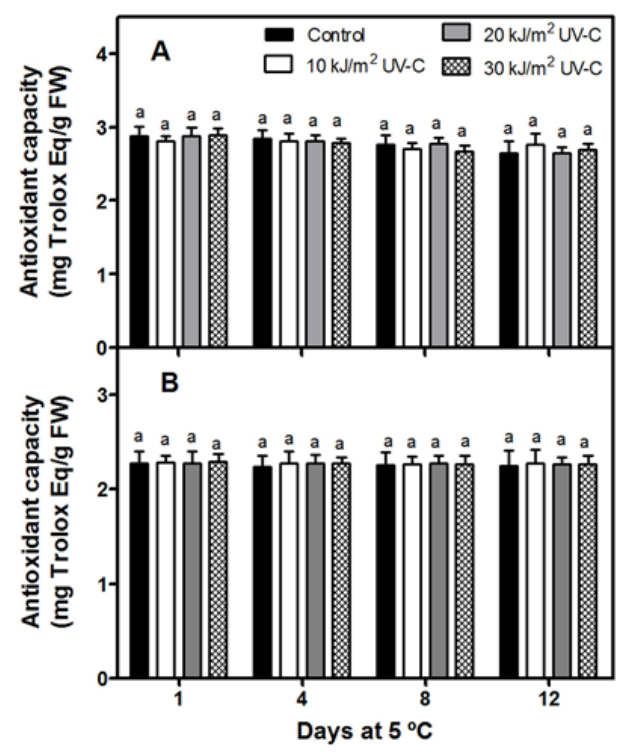

Fig. 4: Antioxidant capacity by DPPH method(A) and by FRAP method (B) of minimally processed rocket leaves untreated (control) and treated with UV-C radiation $(10,20$ and $30 \mathrm{~kJ} / \mathrm{m}^{2}$ ) and stored at $5{ }^{\circ} \mathrm{C}$ for 12 days. Different letters at each storage time represent significant differences at $\mathrm{P}<$ 0.05 according to LSD test.

The evolution of phenolic content and antioxidant capacity in the treatments with gaseous ozone showed similar behavior with respect to the values observed in the UV-C treatments. No significant differences $(\mathrm{P}>0.05)$ between treatments with ozone were found on the processing day or throughout the storage (Fig. 5 and 6).

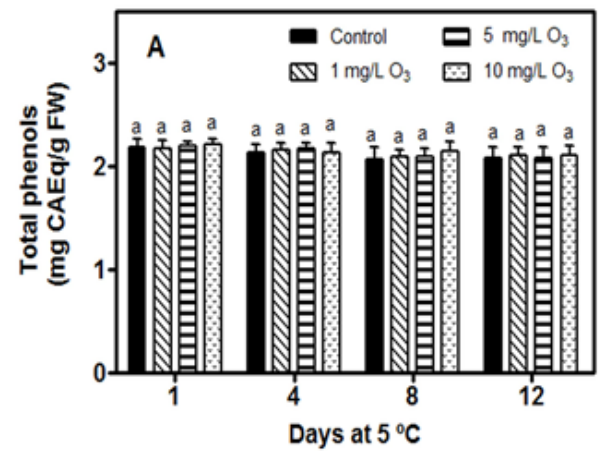


Fig. 5: Content of total phenolics of minimally processed rocket leaves untreated (control) and treated with and treated with gaseous $\mathrm{O}_{3}(1,5$ and $10 \mathrm{mg} / \mathrm{L})$ and stored at $5^{\circ} \mathrm{C}$ for 12 days. Different letters at each storage time represent significant differences at $\mathrm{P}<0.05$ according to LSD test.

These results agree with what was reported by Glowacz and Rees [32] who reported that treatments with ozone $(0.45,0.9$ and $2 \mu \mathrm{mol} / \mathrm{mol}$ ) did not affect the total phenolic content and antioxidant activity of green peppers stored during 14 days at $10{ }^{\circ} \mathrm{C}$. However, Yeoh et al. [12] reported that ozone treatments for 10 or 20 minutes in freshly cut papaya produced a significant increase in the total phenolic content in $8.3 \%$ and $10.3 \%$, respectively. On the other hand, Karaca and Velioglu [24] reported fresh-cut parsley treated with gaseous ozone $(0.950 \pm 12 \mu \mathrm{L} / \mathrm{L}$ for $20 \mathrm{~min})$ with a $41 \%$ reduction in antioxidant activity. These authors reported that sensitivities of phenolics and other antioxidative compounds to oxidative reactions are most probably influenced by the type of these compounds and their location in the cell.

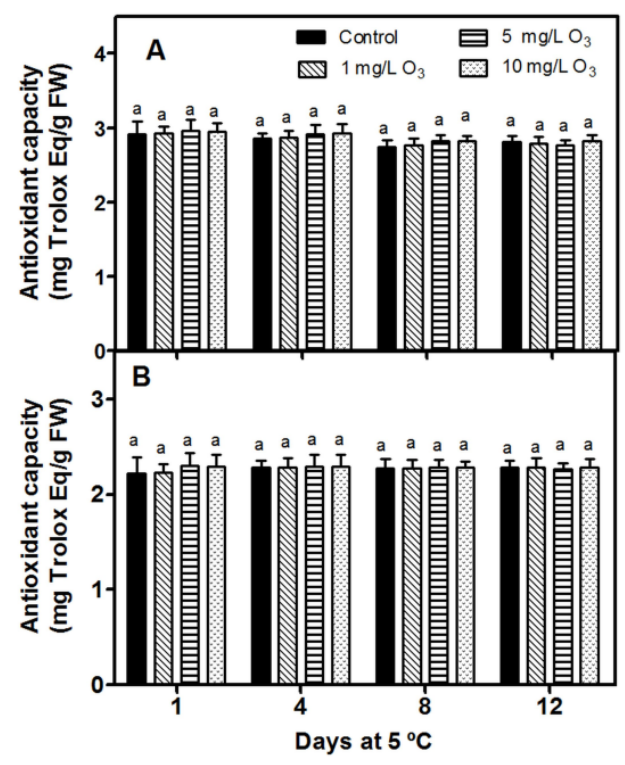

Fig. 6: Antioxidant capacity by DPPH method(A) and by FRAP method (B) of minimally processed rocket leaves untreated (control) and treated with gaseous $\mathrm{O}_{3}(1,5$ and 10 $\mathrm{mg} / \mathrm{L}$ ) and stored at $5{ }^{\circ} \mathrm{C}$ for 12 days. Different letters at each storage time represent significant differences at $\mathrm{P}<0.05$ according to LSD test.

\section{Chlorophyll and Carotenoid Content}

The initial concentration of total chlorophyll in the control was of $98.4 \mathrm{mg} / 100 \mathrm{gFW}$, corresponding around $77 \%$ to chlorophyll a and around $23 \%$ to chlorophyll b (Table 2). After the application of the different doses of UV-C, a reduction of the total chlorophyll concentration was observed, with decreases of $12 \%$ for the higher UV-C dose of $30 \mathrm{~kJ} \mathrm{UV}-\mathrm{C} / \mathrm{m}^{2}$, while that the doses of 10 and $20 \mathrm{~kJ}$ $\mathrm{UV}-\mathrm{C} / \mathrm{m}^{2}$ showed an decreases of approximately $10 \%$ with respect to the control.

The general trend of this parameter, in all the treatments, was a decrease throughout the shelf life at $5{ }^{\circ} \mathrm{C}$. However, the treatments with UV-C had a lower degradation rate than controls. At 12 days, only significant differences were observed between control and samples treated with $20 \mathrm{~kJ}$ $\mathrm{UV}-\mathrm{C} / \mathrm{m}^{2}$. These results agree with what reported by Tomás-Callejas et al. [39], who observed that treatments with UV-C radiation $\left(4.54 \mathrm{~kJ} / \mathrm{m}^{2}\right)$ did not cause significant changes in the total chlorophyll content.

Table 2: Changes in the content of chlorophyll a, chlorophyll $\mathrm{b}$ and total chlorophyll and carotenoid of minimally processed rocket leaves untreated (control) and treated with UV-C radiation $(10,20$ and $30 \mathrm{~kJ} / \mathrm{m} 2)$ and stored at $5{ }^{\circ} \mathrm{C}$ for 12 days.

\begin{tabular}{|ccccc|}
\hline \multirow{2}{*}{ Storage time at 5 ${ }^{\circ} \mathrm{C}$} & \multicolumn{4}{c|}{ Treatments } \\
\cline { 2 - 5 } & Control & $10 \mathrm{~kJ} / \mathrm{m}^{2} \mathrm{UV}-\mathrm{C}$ & $20 \mathrm{~kJ} / \mathrm{m}^{2} \mathrm{UV}-\mathrm{C}$ & $30 \mathrm{~kJ} / \mathrm{m}^{2} \mathrm{UV}-\mathrm{C}$ \\
\hline Chlorophyll a (mg/100 g F.W) & & & \\
Day 1 & $76.2 \mathrm{a}^{\mathrm{A}}$ & $69.2 \mathrm{~b}^{\mathrm{A}}$ & $69.4 \mathrm{~b}^{\mathrm{A}}$ & $67.6 \mathrm{c}^{\mathrm{A}}$ \\
Day 4 & $65.3 \mathrm{ab}^{\mathrm{B}}$ & $64.8 \mathrm{ab}^{\mathrm{A}}$ & $68.1 \mathrm{a}^{\mathrm{A}}$ & $64.8 \mathrm{ab}^{\mathrm{A}}$ \\
Day 8 & $71.4 \mathrm{a}^{\mathrm{AB}}$ & $65.0 \mathrm{a}^{\mathrm{A}}$ & $69.4 \mathrm{a}^{\mathrm{A}}$ & $66.2 \mathrm{a}^{\mathrm{A}}$ \\
Day 12 & $54.5 \mathrm{~b}^{\mathrm{C}}$ & $55.9 \mathrm{ab}^{\mathrm{B}}$ & $61.5 \mathrm{a}^{\mathrm{B}}$ & $52.2 \mathrm{~cd}^{\mathrm{B}}$ \\
Chlorophyll b (mg/100 g F.W) & & & & \\
Day 1 & $22.1 \mathrm{a}^{\mathrm{AB}}$ & $22.2 \mathrm{a}^{\mathrm{A}}$ & $22.2 \mathrm{a}^{\mathrm{A}}$ & $19.7 \mathrm{a}^{\mathrm{A}}$ \\
Day 4 & $22.9 \mathrm{ab}^{\mathrm{A}}$ & $21.5 \mathrm{ab}^{\mathrm{A}}$ & $21.5 \mathrm{ab}^{\mathrm{A}}$ & $18.9 \mathrm{c}^{\mathrm{A}}$ \\
Day 8 & $19.4 \mathrm{a}^{\mathrm{AB}}$ & $19.1 \mathrm{a}^{\mathrm{A}}$ & $19.1 \mathrm{a}^{\mathrm{A}}$ & $18.2 \mathrm{a}^{\mathrm{A}}$ \\
Day 12 & $16.7 \mathrm{~b}^{\mathrm{B}}$ & $21.6 \mathrm{a}^{\mathrm{A}}$ & $21.6 \mathrm{a}^{\mathrm{A}}$ & $21.7 \mathrm{a}^{\mathrm{A}}$ \\
Total chlorophyll (mg/100 g F.W) & & & \\
Day 1 & $98.4 \mathrm{a}^{\mathrm{A}}$ & $91.4 \mathrm{~b}^{\mathrm{A}}$ & $90.1 \mathrm{~b}^{\mathrm{A}}$ & $87.3 \mathrm{bc}^{\mathrm{A}}$ \\
Day 4 & $88.2 \mathrm{ab}^{\mathrm{B}}$ & $86.3 \mathrm{ab}^{\mathrm{AB}}$ & $88.1 \mathrm{ab}^{\mathrm{AB}}$ & $83.7 \mathrm{ab}^{\mathrm{A}}$ \\
Day 8 & $90.9 \mathrm{a}^{\mathrm{AB}}$ & $84.2 \mathrm{a}^{\mathrm{AB}}$ & $86.8 \mathrm{a}^{\mathrm{AB}}$ & $84.3 \mathrm{a}^{\mathrm{AB}}$ \\
Day 12 & $71.2 \mathrm{~b}^{\mathrm{C}}$ & $77.6 \mathrm{ab}^{\mathrm{B}}$ & $80.7 \mathrm{a}^{\mathrm{B}}$ & $73.9 \mathrm{ab}^{\mathrm{B}}$ \\
Total carotenoids (mg/100g F.W) & & & \\
Day 1 & $24.4 \mathrm{a}^{\mathrm{A}}$ & $20.4 \mathrm{~b}^{\mathrm{A}}$ & $21.7 \mathrm{ab}^{\mathrm{A}}$ & $21.1 \mathrm{~b}^{\mathrm{A}}$ \\
Day 4 & $19.2 \mathrm{a}^{\mathrm{BC}}$ & $20.1 \mathrm{a}^{\mathrm{A}}$ & $20.9 \mathrm{a}^{\mathrm{A}}$ & $20.4 \mathrm{a}^{\mathrm{A}}$ \\
Day 8 & $21.0 \mathrm{a}^{\mathrm{AB}}$ & $18.5 \mathrm{a}^{\mathrm{A}}$ & $21.3 \mathrm{a}^{\mathrm{A}}$ & $19.8 \mathrm{a}^{\mathrm{A}}$ \\
Day 12 & $15.9 \mathrm{a}^{\mathrm{C}}$ & $15.7 \mathrm{a}^{\mathrm{B}}$ & $16.6 \mathrm{a}^{\mathrm{B}}$ & $14.3 \mathrm{a}^{\mathrm{B}}$ \\
\hline
\end{tabular}

Mean values in the same row with different lowercase letters or in the same column for same type sample with different superscript letters were significantly different according to LSD test at $\mathrm{P}<0.05$.

Regarding carotenoid content, it was observed that the control and the treatments presented similar initial values in a range of 20.4 to $24.4 \mathrm{mg} \mathrm{100/g} \mathrm{FW.} \mathrm{During} \mathrm{storage} \mathrm{a}$ significant decrease $(\mathrm{p}<0.05)$ for all treatments was observed. At day 12 the total carotenoids content ranged between 14.3 and $16.6 \mathrm{mg} / 100 \mathrm{~g} \mathrm{FW}$, with a decreased value of $27-35 \%$ regarding the initial value, and no significant differences were observed between the treated samples and the control (Table 2). On the other hand, Martínez-Hernandez et al. [40] reported that treatments with UV-C radiation $(1.5,4.5,9.0$ and $15.0 \mathrm{~kJ} \mathrm{UV-C} / \mathrm{m}^{2}$ ) in broccoli produced a reduction of the total carotenoid content from 6 to $20 \%$ with respect to the control. However, the total carotenoid content through storage remained constant for the treated samples, while the control decreased by $26 \%$ with respect to the start.

In the treatments with ozone, the initial total chlorophyll content was similar for all treatments, ranging from 92.0 to $95.6 \mathrm{mg} / 100 \mathrm{~g} \mathrm{FW}$, corresponding around $75 \%$ to chlorophyll a and around $25 \%$ to chlorophyll b (Table 3). Subsequently, the total chlorophyll content significantly decreased and remained steady for all treatments throughout the shelf life. 
At the end of storage, the control and samples treated with $\mathrm{O}_{3}$ showed total chlorophyll concentrations between 81.0 and $86.9 \mathrm{mg} / 100 \mathrm{~g} \mathrm{~F}$.W, with a decreased value of $10-12 \%$ from the initial value. No significant differences were found between the treated samples and the control throughout the conservation at $5{ }^{\circ} \mathrm{C}$.

In the same way, Karaca and Velioglu [24] reported that treatments with gaseous ozone did not cause significant changes in the total chlorophyll content of parsley. However, other authors reported that the application of ozone caused discoloration in lettuce [33] and spinach [41].

Regarding the content of carotenoids, initially there were no differences between the control and treatments with ozone, presenting values in a range of 20.4 to $24.4 \mathrm{mg} / 100 \mathrm{~g} \mathrm{~F}$.W (Table 3). During storage, it was observed that this parameter presented an evolution similar to that of chlorophyll, that is, a significant decrease in all the treatments. At day 12 the total carotenoids content ranged between 15.7 and $16.6 \mathrm{mg} / 100 \mathrm{~g}$ F.W, with a decreased value of $24-35 \%$ from the initial value, and no significant differences were observed between the all treatments. Similar results were reported with gaseous ozone treatments that did not cause significant changes in the lycopene content [32] and carotenoid (beta carotene, lutein and lycopene composition) of tomato fruit [42].

Table 3: Changes in the content of chlorophyll a, chlorophyll $\mathrm{b}$ and total chlorophyll and carotenoid of minimally processed rocket leaves untreated (control) and treated with UV-C radiation $(10,20$ and $30 \mathrm{~kJ} / \mathrm{m} 2)$ and stored at $5^{\circ} \mathrm{C}$ for 12 days.

\begin{tabular}{|ccccc|}
\hline \multirow{2}{*}{ Storage time at 5 ${ }^{\circ} \mathrm{C}$} & \multicolumn{4}{c|}{ Treatments } \\
\cline { 2 - 5 } Control & $1 \mathrm{mg} / \mathrm{LO}_{3}$ & $5 \mathrm{mg} / \mathrm{LO}_{3}$ & $10 \mathrm{mg} / \mathrm{LO}_{3}$ \\
\hline Chlorophyll a (mg/100 g F.W) & & & & \\
Day 1 & $70.3 \mathrm{a}^{\mathrm{A}}$ & $69.0 \mathrm{a}^{\mathrm{A}}$ & $69.4 \mathrm{a}^{\mathrm{A}}$ & $69.8 \mathrm{a}^{\mathrm{A}}$ \\
Day 4 & $67.6 \mathrm{a}^{\mathrm{AB}}$ & $63.5 \mathrm{a}^{\mathrm{B}}$ & $66.5 \mathrm{a}^{\mathrm{AB}}$ & $64.8 \mathrm{a}^{\mathrm{A}}$ \\
Day 8 & $61.1 \mathrm{a}^{\mathrm{B}}$ & $61.6 \mathrm{a}^{\mathrm{B}}$ & $59.6 \mathrm{a}^{\mathrm{B}}$ & $61.6 \mathrm{a}^{\mathrm{A}}$ \\
Day 12 & $62.3 \mathrm{a}^{\mathrm{B}}$ & $65.1 \mathrm{a}^{\mathrm{AB}}$ & $61.2 \mathrm{a}^{\mathrm{B}}$ & $61.3 \mathrm{a}^{\mathrm{A}}$ \\
Chlorophyll b (mg/100 g F.W) & & & & \\
Day 1 & $25.3 \mathrm{a}^{\mathrm{A}}$ & $25.5 \mathrm{a}^{\mathrm{A}}$ & $22.6 \mathrm{a}^{\mathrm{A}}$ & $21.9 \mathrm{a}^{\mathrm{A}}$ \\
Day 4 & $20.7 \mathrm{a}^{\mathrm{B}}$ & $21.3 \mathrm{a}^{\mathrm{AB}}$ & $20.5 \mathrm{a}^{\mathrm{AB}}$ & $20.1 \mathrm{a}^{\mathrm{A}}$ \\
Day 8 & $22.2 \mathrm{a}^{\mathrm{AB}}$ & $22.4 \mathrm{a}^{\mathrm{AB}}$ & $21.3 \mathrm{a}^{\mathrm{AB}}$ & $19.9 \mathrm{a}^{\mathrm{A}}$ \\
Day 12 & $23.7 \mathrm{a}^{\mathrm{AB}}$ & $19.8 \mathrm{~b}^{\mathrm{B}}$ & $19.7 \mathrm{~b}^{\mathrm{B}}$ & $18.2 \mathrm{c}^{\mathrm{A}}$ \\
Total chlorophyll (mg/100 g F.W) & & & \\
Day 1 & $95.6 \mathrm{a}^{\mathrm{A}}$ & $94.6 \mathrm{a}^{\mathrm{A}}$ & $92.0 \mathrm{a}^{\mathrm{A}}$ & $91.7 \mathrm{a}^{\mathrm{A}}$ \\
Day 4 & $88.2 \mathrm{a}^{\mathrm{AB}}$ & $84.8 \mathrm{a}^{\mathrm{B}}$ & $87.1 \mathrm{a}^{\mathrm{AB}}$ & $84.9 \mathrm{a}^{\mathrm{A}}$ \\
Day 8 & $83.3 \mathrm{a}^{\mathrm{B}}$ & $84.0 \mathrm{a}^{\mathrm{B}}$ & $80.9 \mathrm{a}^{\mathrm{B}}$ & $81.5 \mathrm{a}^{\mathrm{A}}$ \\
Day 12 & $86.0 \mathrm{ab}^{\mathrm{B}}$ & $84.9 \mathrm{ab}^{\mathrm{B}}$ & $81.0 \mathrm{ab}$ & $79.5 \mathrm{ab}^{\mathrm{A}}$ \\
Total carotenoids (mg/100g F.W) & & & \\
Day 1 & $24.3 \mathrm{a}^{\mathrm{A}}$ & $22.8 \mathrm{a}^{\mathrm{A}}$ & $21.2 \mathrm{a}^{\mathrm{B}}$ & $20.5 \mathrm{a}^{\mathrm{A}}$ \\
Day 4 & $20.5 \mathrm{a}^{\mathrm{AB}}$ & $19.0 \mathrm{a}^{\mathrm{B}}$ & $20.8 \mathrm{a}^{\mathrm{AB}}$ & $19.4 \mathrm{a}^{\mathrm{A}}$ \\
Day 8 & $17.8 \mathrm{a}^{\mathrm{BC}}$ & $17.6 \mathrm{a}^{\mathrm{B}}$ & $17.7 \mathrm{a}^{\mathrm{C}}$ & $17.9 \mathrm{a}^{\mathrm{A}}$ \\
Day 12 & $16.9 \mathrm{a}^{\mathrm{C}}$ & $18.2 \mathrm{a}^{\mathrm{B}}$ & $18.5 \mathrm{a}^{\mathrm{C}}$ & $18.9 \mathrm{a}^{\mathrm{A}}$ \\
\hline
\end{tabular}

Mean values in the same row with different lowercase letters or in the same column for same type sample with different superscript letters were significantly different according to LSD test at $\mathrm{P}<0.05$.

\section{CONCLUSIONS}

Based on the findings of this paper, the UV-C radiation and gaseous ozone treatments retained the quality attributes of minimally processed rocket leaves during refrigerated storage. The content of ascorbic acid was not affected by the treatments with UV-C and ozone and then decreased during storage at $5{ }^{\circ} \mathrm{C}$. Total phenols and antioxidant capacity were also not affected by these treatments and remained stable through the cold storage.Moreover, treatments with UV-C delayed the degradation of total chlorophyll content throughout shelf-life, while the treatments with $\mathrm{O}_{3}$ did not affect this parameter.As non- contaminant technologies, UV-C treatments in appropriate doses $\left(10,20\right.$ and $\left.30 \mathrm{~kJ} / \mathrm{m}^{2}\right)$ and gaseous ozone $(1,5$ and $10 \mathrm{mg} / \mathrm{L})$ could be feasible to maintain the bioactive compounds with antioxidant activity content of minimally processed rocket leaves for 12 days storage at $5{ }^{\circ} \mathrm{C}$.

\section{ACKNOWLEDGMENTS}

Special thanks to ICyTA-FAyA-UNSE, CICyT-UNSE, PIO-UNSE 2015, PICT 2016- 01529 and CONICET which finances Dr. Gutierrez's training grant.

\section{REFERENCES}

[1] Ali A., Ong M.K. and Forney C.F., Effect of ozone pre-conditioning on quality and antioxidant capacity of papaya fruit during ambient storage. Food Chem. 142(2014) 19-26.

[2] Radziejewska-Kubzdela, E., The effect of pretreatment and modified atmosphere packaging on bioactive compound content in coleslaw mix. LWT-Food Sci. Technol. 75(2017) 505-511.

[3] Zhang, J., Yuan, L., Liu, W., Lin, Q., Wang, Z., \& Guan, W. Effects of UV-C on antioxidant capacity, antioxidant enzyme activity and colour of fresh-cut red cabbage during storage. International J. Food Sci. Technol. 52(3)(2017) 626-634.

[4] Nunes T.P., Martins C.G., Faria A.F., Biscola V., De Oliveira Souza K.L., Mercadante A.Z. and Landgraf M.,Changes in total ascorbic acid and carotenoids in minimally processed irradiated Arugula (Eruca sativa Mill) stored under refrigeration. Radiat. Phys. Chem. 90(2013) $125-130$.

[5] Gutiérrez, D.R., Char, C., Escalona, V.H., Chaves, A.R., Rodríguez, S.D.C., Application of UV-C radiation in the conservation of minimally processed rocket(Eruca sativa Mill.). J. Food Process. Preserv. 39 (6)(2015) 3117-3127.

[6] Gutiérrez D.R., Chaves A.R., Rodriguez S.C. Use of UV-C and gaseous ozone as sanitizing agents for keeping the quality of fresh-cut rocket (Eruca sativa Mill.). J Food Proc. Preservat. 00 (2016) 1-13.

[7] Gutiérrez, D. R., Chaves, A. R., and Rodríguez, S. D. C., UV-C and ozone treatment influences on the antioxidant capacity and antioxidant system of minimally processed rocket (Eruca sativa Mill.). Postharvest Biol. Technol. 138 (2018) 107-113.

[8] Zimmer A.R., Leonardi, B., Miron, D., Schapoval, E., Oliviera, J., and Gosmann, G., Antioxidant and anti-inflammatory properties of Capsicum baccatum:From traditional use to scientific approach. J. Ethnopharmacology, 139 (2012) 228-233.

[9] Sachadyn-Król, M., Materska, M., Chilczuk, B., Karaś, M., Jakubczyk, A., Perucka, I., and Jackowska, I., Ozone-induced changes in the content of bioactive compounds and enzyme activity during storage of pepper fruits. Food Chem. 211(2016) 59-67.

[10] Materska M., Bioactive phenolics of fresh and freeze-dried sweet and semispicypepper fruits (Capsicum annuиm L.). J. Functional Foods. 7 (2014) 269-277.

[11] [11] Rico D., Martin-Diana A.B., Barat J.M. and Barry-Ryan C., Extending and measuring the quality of fresh-cut fruit and vegetables: A review. Trends Food Sci. Technol. 18(2007) 373-386.

[12] [12] Yeoh, W. K., Ali, A., and Forney, C. F., Effects of ozone on major antioxidants and microbial populations of fresh-cut papaya. Postharvest Biol.Technol. 89 (2014) 56-58.

[13] PataroG., SinikM., Capitoli M.M., Donsì G. and Ferrari G., The influence of post-harvest UV-C and pulsed light treatments on quality and antioxidant properties of tomato fruits during storage. Innovative Food Sci. Emerging Technol. 30 (2015) 103-111. 
[14] Lemoine M.L., Civello P., Chaves A. and Martinez G., Hot air treatment delays senescence and maintains quality of fresh-cut broccoli florets during refrigerated storage. LWT - Food Sci. Technol. 42 (2009) 1076-1081.

[15] Bintsis, T., Litopoulou-Tzanetaki, E., Robinson, R.K., Existing and potentialapplications of ultraviolet light in the food industry-a critical review. J. Sci.Food Agric. 80, (2000) 637-645.

[16] Artés-Hernández F., Robles P.A., Gómez P.A., Tomás-Callejas A., Artés F.,Low UV-C illumination for keeping overall quality of fresh-cut watermelon. Postharvest Biol. Technol. 55 (2010) 114-120.

[17] Cisneros-Zevallos, L., The use of controlled postharvest abiotic stresses as atool for enhancing the nutraceutical content and adding-value of fresh fruits and vegetables. J. Food Sci. 68(2003) 1560-1565.

[18] ShenY., SunY., QiaoL., ChenJ., Liu D., YeX., Effect of UV-C treatments on phenolic compounds and antioxidant capacity of minimally processed Satsuma mandarin during refrigerated storage. Postharvest Biol. Technol. 76 (2013) 50-57.

[19] Alothman, M., Bhat, R., Karim, A.A., UV radiation-induced changes ofantioxidant capacity of fresh-cut tropical fruits. J. Innov. Food Sci Emerg.Technol. 10 (4)(2009) 512-516.

[20] Sari, L. K., Setha, S., and Naradisorn, M., Effect of UV-C irradiation on postharvest quality of 'Phulae'pineapple. Scientia Horticulturae, 213(2016) 314-320.

[21] González-Aguilar, G.A., Villegas-Ochoa, M.A., Martínez-Téllez, M.A., Gardea, A.A., Ayala-Zavala, J.F., Improving antioxidant capacity of fresh-cut mangoes treated with UV-C. J. Food Sci. 72 (2007) 197-202.

[22] Erkan M., Wang S.Y. and Wang C.Y., Effect of UV treatment on antioxidant capacity, antioxidant enzyme activity and decay in strawberry fruit. Postharvest Biol. Technol. 48(2008) 163-171.

[23] Bravo S., García-Alonso J., Martín-Pozuelo G., Gómez V., Santaella M., Navarro-González I. andPeriago M.J.,The influence of post-harvest UV-C hormesis on lycopene, $\beta$-carotene, and phenolic content and antioxidant activity of breaker tomatoes. Food research international. 49(1)(2012) 296-302.

[24] Karaca H. and Velioglu Y.S., Effects of ozone treatments on microbial quality and some chemical properties of lettuce, spinach, and parsley. Postharvest Biol. Technol. 88 (2014) 46-53.

[25] [25] Forney, C.F., Postharvest response of horticultural products to ozone. In: Hodges,D.M. (Ed.), Postharvest Oxidative Stress in Horticultural Crops. Food Products Press,New York, NY, (2003) pp. $13-54$.

[26] Kampfenkel, K., Montagu, M.V., Inzé, D., Extraction and determination of ascorbateand dehydroascorbate from plant tissue. Anal. Biochem. 225 (1995)165-167.

[27] SingletonV.L., Orthofer R., Lamuela-Raventós R.M., Analysis of total phenols and other oxidation substrates and antioxidants by means of Folin-Ciocalteau reagent. Methods in enzymology. 299 (1999) $152-153$.

[28] Benzie, I.F.F., Strain, J.J., The ferric reducing ability of plasma (FRAP) as ameasure of 'antioxidant power': the FRAP assay. Analytical Biochemistry 239 (1996) 70-76.

[29] Brand WilliamsW., Cuvelier M.E. and Berset C., Use of a free radical method to evaluate antioxidant activity. LWT-Food sci.Technol. 28(1995) 25-30.

[30] Lichtenthaler H.K., Chlorophylls and carotenoids: pigments of photosynthetic biomembranes. Methods Enzymology. 148 (1987) 350-382.

[31] Perkins-VeazieP., CollinsJ.K., HowardL., Blueberry fruit response to postharvest application of ultraviolet radiation. Postharvest Biol. Technol. 47(2008) 280-285.

[32] GlowaczM. and ReesD., "Exposure to ozone reduces postharvest quality loss in red and green chilli peppers", Food Chemistry, vol. 210(2016) 305-310.

[33] Aguayo E., Escalona V.H. and Artés F., Effect of cyclic exposure to ozone gas on physicochemical, sensorial and microbial quality of whole and sliced tomatoes. Postharvest Biol. Technol. 39(2006) 169-177.

[34] Olmez H. and Akbas M.Y., Optimization of ozone treatment of fresh-cut green leaf lettuce. J. Food Eng. 90(2009) 487-494

[35] Chauhan, O.P., Raju, P.S., Ravi, N., Singh, A., Bawa, A.S., Effectiveness of ozone in combination with controlled atmosphere on quality characteristic includinglignification of carrot sticks. J. Food Eng. 102 (2011) 43-48.

[36] Martinez-Hernandez G.B., Artés-Hernandez F., Gomez P.A., Formica A.C. and Artés F. Combination of electrolyzed water, UV-C and super atmospheric $\mathrm{O}_{2}$ packaging for improving fresh-cut broccoli quality. Postharvest Biol. Technol. 76 (2013) 125-134.
[37] Jin, P., Yao, D., Xu, F., Wang, H., Zheng, Y., Effect of light on quality and bioactive compounds in postharvest broccoli florets. Food Chem. 172(2015) 705-709.

[38] Huang, H., Ge, Z., Limwachiranon, J., Li, L., Li, W., and Luo, Z., UV-C treatment affects browning and starch metabolism of minimally processed lily bulb. Postharvest Biol. Technol. 128 (2017) 105-111.

[39] Park, M.H., Kim, J.G., Low-dose UV-C irradiation reduces the microbial population and preserves antioxidant levels in peeled garlic (Allium sativum L.) during storage. Postharvest Biol. Technol. 100(2015) 109-112.

[40] Tomás-Callejas A., Otón M., Francisco Artés F., Artés-Hernández F. Combined effect of UV-C pretreatment and high oxygen packaging for keeping the quality of fresh-cut Tatsoi baby leaves. Innovative Food Sci. Emerging Technol. 14(2012) 115-121.

[41] Martínez-Hernández G.B., Gómez P.A., Pradas I., Artés F., Artés-Hernández F., Moderate UV-C pretreatment as a quality enhancement tool in fresh-cut Bimi ${ }^{\circledR}$ broccoli. Postharvest Biol. Technol. 62 (2011) 327-337.

[42] Vurma M., Pandit R.B., Sastry S.K. and Yousef A.E., Inactivation of Escherichia coli O157:H7 and natural microbiota on spinach leaves using gaseous ozone during vacuum cooling and simulated transportation. J. Food Protect. 72(2009)1538-1546.

[43] Tzortzakis N., Borland A., Singleton I. and Barnes S, J., Impact of atmospheric ozone-enrichment on quality-related attributes of tomato fruit. Postharvest Biol. Technol. 45(2007) 317-325.

Gutierrez Diego: PhD. Posdoc student at CONICET-Argentina. Topics of research: -Postharvest conservation and application of emerging technologies in the conservation of fresh cut vegetables. -Effect of postharvest technologies on plant physiology and quality. -Evaluation of the sensorial, nutritional and microbiological quality of foods. -Evaluation of shelf life of vegetables.

Lemos Laura: Food Engineer. PhD student at CONICET-Argentina. Topics of research: -Postharvest conservation and application of emerging technologies in the conservation of fresh cut vegetables. -Effect of postharvest technologies on plant physiology and quality. -Evaluation of the sensorial, nutritional and microbiological quality of foods. -Evaluation of shelf life of vegetables.

Rodriguez Silvia: PhD. Professor at National University of Santiago del Estero-Argentina since 1993. Topics of research:-Conservation of fruit and vegetable. -Postharvest conservation and application of emerging technologies in the conservation of fresh cut vegetables. -Effect of postharvest technologies on plant physiology and quality. -Evaluation of the sensorial, nutritional and microbiological quality of foods. -Evaluation of shelf life of vegetables. 